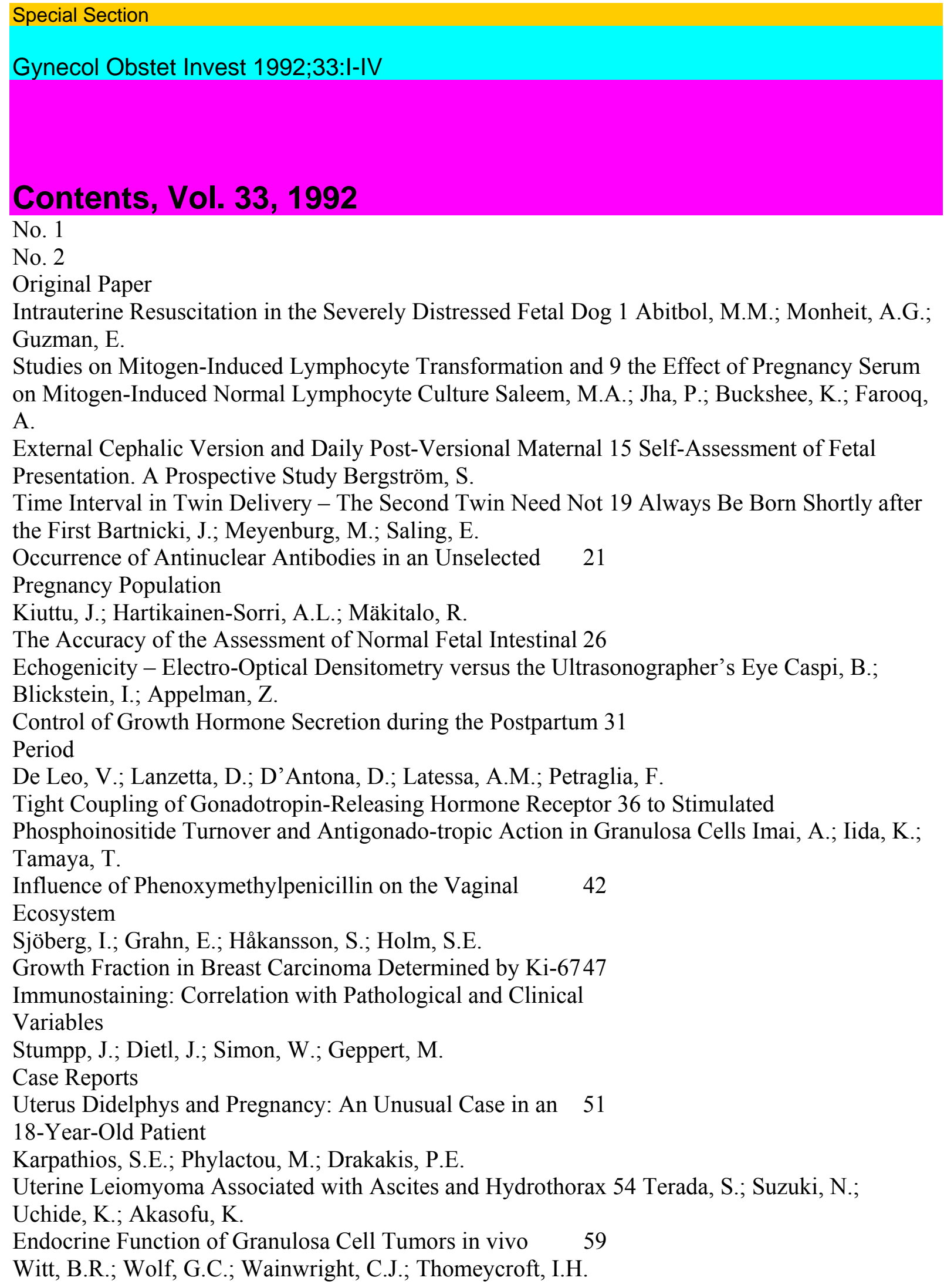


Original Paper

Effects of Methotrexate on Rabbit Oviducts and on Cell 65

Cultures of Bovine Oviduct Epithelium

Tepper, R.; Nahum, R.; Rahamim, E.; Kapolovitz, Y.; Segal, Y.;

Karib, N.; Beyth, Y.

Lectin Cytochemistry of Mouse Vaginal Smears $\quad 69$

Vrcic, H.; Horvat, B.; Damjanov, I.

Ultrasound Pulsed Doppler Studies of the Uteroplacental 75

Circulation: The Influence of Sampling Site and Placenta

Implantation

Oosterhof, H,; Aarnoudse, J.G.

Demonstration of Tumor Necrosis Factor- $\alpha$ in Preovulatory 80

Follicular Fluid: Its Association with Serum 17ß-Estradiol and

Progesterone

Punnonen, J,; Heinonen, P.K.; Teisala, K.; Kujansuu, E.; Jansen, C.T.;

Punnonen, R.

Dexamethasone Inhibits Basal and Stimulated Prostaglandin 85 E2 Output from Human

Placental Cells by Inhibition of Prostaglandin H Synthase Riley, S.C.; Greer, LA.; Schembri, L.A.; Challis, J.R.G.

Gestational Duration and Birth Weight for Twins Related to 90 Fetal Sex

Rydhström, H.

Density Distribution of Erythrocyte Population in Pre- 94

eclampsia

Lurie, S.

Menopausal Hot Flushes, Plasma Calcitonin and Beta- 98

Endorphin. A Preliminary Report Tepper, R.; Pardo, J.; Ovadia, J.; Beyth, Y.

Compensatory Mechanisms Which Prevent Urinary Inconti- 102

nence in Aging Women

Wijma, J.; Tinga, D.J.; Visser, G.H.A.

Treatment and Results of Chronic Toxoplasmosis. Analysis of 105

33 Cases

Cengir, S.D.; Ortaç, F.; Söylemez, F.

Enhancement of Growth-Promoting Activity in Extract from 109 Uterine Cancers by Protein

Kinase $\mathrm{C}$ in Human Endometrial Fibroblasts

Imai, A.; Matsunami, K.; Ohno, T.; Tamaya, T.

Leiomyosarcoma of the Uterus: Ultrasonography and Serum 114 Lactate Dehydrogenase Level

Seki, K.; Hoshihara, T.; Nagata, I.

II

Could Bacterial Vaginosis Be Due to the Competitive Suppres- 119 sion of Lactobacilli by

Aerobic Microorganisms? Fredricsson, B.; Englund, K.; Nord, C.E.; Weintraub, L.

Short Communication

Maternal Plasma Fibronectin and Neonatal Birth Weight

124

Tamás, P.; Feledi, É.; Ertl, T.; Kett, A.; Werling, J.

Case Report

Multiple Congenital Arteriovenous Malformations with 
Involvement of the Vagina and Profuse Hemorrhage from Vaginal Ulcer Sholapurkar, S.L.;

Malhotra, S.; Dhall, K.; Kochhar, S.

No. 3

Original Paper

Effects of Prolactin on Secretion and Synthesis of Human 129

Chorionic Gonadotropin in Human Term Placentas in vitro: Short-Term Increase in Secretion, Followed by Medium-Term Suppression of Synthesis and Secretion Würfel, W.; Beckmann, M.W.; Austin, R.; Herzog, U.; Albert, P.J.

Betamethasone-Induced Lecithin Release in vitro from the 134

Fetal Membranes

Vesce, F.; Pareschi, M.C.; Travagli, S.; Tarabbia, C; Pansini, F.; Salvatorelli, G.; Gulinati, A.M.;

Grandi, E.; Biondi, C.

Serum Angiotensin-Converting Enzyme Activity in Pregnancy- 138 Induced Hypertension Li, J.;

Hu, H.-Y.; Zhao, Y.-N.

Localization of 15-Hydroxy Prostaglandin Dehydrogenase in 142

Human Fetal Membranes, Decidua, and Placenta during

Pregnancy

Cheung, P.Y.C.; Walton, J.C.; Tai, H.-H.; Riley, S.C.; Challis, J.R.G.

Plasma Fibronectin Receptor Levels during Pregnancy Compli- 147 cated by Preeclampsia and Abruptio placentae Kanayama, N.; Terao, T.

Tetraploidy in Human Placenta. A Dilemma in Molar and 153

Non-Molar Pregnancies

Tóth, A.; Arató, G; Szepesi, J.; Hajdu, K.; Szigetvári, I.; László, J.

Effect of Serum from Patients with Endometriosis on the 157

Development of Mouse Embryos

Abu-Musa, A.; Takahashi, K.; Kitao, M.

Conservative Treatment of Ectopic Pregnancy and Its Effect 161 on Corpus luteum Activity

Shulman, A.; Maymon, R.; Zmira, N.; Lotan, M.; Holtzinger, M.; Bahary, C.

Measurement of Noradrenaline, Dopamine and Serotonin 165

Contents in Follicular Fluid of Human Graafian Follicles after Superovulation Treatment Bòdis,

J.; Bognàr, Z.; Hartmann, G.; Török, A.; Csaba, I.F.

Intranasal Salmon Calcitonin in Postmenopausal Osteoporosis: 168

Effect of Different Therapeutic Regimens on Vertebral and

Peripheral Bone Density

Perrone, G.; Galoppi, P.; Valente, M.; Capri, O.; D’Ubaldo, C;

Anelli, G.; Zichella, L.

CO2 Laser Vaporization in the Treatment of Cervical Human 172

Papillomavirus Infection in Women with Abnormal Papanico-

laou Smears

Ruge, S.; Felding, C; Skouby, S.O.; Lundvall, F.; Hørding, U.;

Norrild, B.

CA-125, Placental Alkaline Phosphatase and Tissue Poly- 177

peptide Antigen as Preoperative Serum Markers in Ovarian

Carcinoma

Toftager-Larsen, K,; Hørding, U.; Dreisler, A.; Daugaard, S.; Lund, B.;

Bock, J.; Lundvall, F.; Frederiksen, K.; Nørgaard-Pedersen, B. 


\section{Current Investigations}

Increased Rate of Preterm Deliveries in Untreated Women 183

with Luteal Phase Deficiencies. Preliminary Report Check, J.H.; Lee, G.; Epstein, R.; Vetter, B. Antibiotic Concentration in Maternal Blood, Cord Blood and 185 Placental Tissue in Women with Chorioamnionitis Maberry, M.C.; Trimmer, K.J.; Bawdon, R.E.; Sobhi, S.; Dax, J.B.;

Gilstrap, L.C. Ill

Case Reports

Successful Outcomes of Pregnancy Complicated with Dermato- 187 myositis. Case Reports Ohno, T.; Imai, A.; Tamaya, T.

Multiple Follicles in an Unstimulated Cycle despite Elevated 190 Gonadotropins in a Perimenopausal Female Check, J.H.

No. 4

Original Paper

Effects of Exogenous Prostacyclin on Placental Blood Flow,

Placental Weight and Fetal Weight in Normotensive and Spontaneously Hypertensive Rats Furuhashi, N.; Tsujiei, M.; Kimura, H.; Yajima, A.

The Decidua of Early Human Pregnancy: Immunohisto- 197

chemistry and Function of Immunocompetent Cells Dietl, J.; Ruck, P.; Horny, H.-P.;

Handgretinger, R.; Marzusch, K.; Ruck, M.; Kaiserling, E.; Griesser, H.; Kabelitz, D.

Heparin Neutralization by an Extract of the Human Placenta: 205 Measurements and the

Concept of Placental Barrier to Heparin Uszyński, M.

Fetal Atrial Measurements before and after Delivery: Correla- 209 tion with Plasma Atrial

Natriuretic Peptide Hata, T.; Makihara, K.; Manabe, A.; Hata, K.; Kitao, M.

Ill

Action of Alpha-Methyldopa on Human Umbilical Circulation 213 in vitro

Franca, L.C.; Pereira da Cunha, S.; Salles Meirelles, R.; Cascaes Dias, C; Yassin, A.

Differential Diagnosis of Early Human Pregnancies: Impact of 216

Different Diagnostic Measures

Thorburn, J.; Bryman, I.; Hahlin, M.; Lindblom, B.

Post-Partum Contraceptive Preference in High-Risk 221

Parturients in Maputo

Bergström, S.

Endogenous Estradiol and Progesterone Concentrations in 224

Smokers on Oral Contraceptives

Basu, J.; Mikhail, M.S.; Palan, P.R.; Thysen, B.; Bloch, E.; Romney, S.L.

Evaluation of the Clinical Method of Measuring Cervical Dila- 228

tation after Treatment of the Cervix prior to First Trimester

Abortion

Molin, A.; Brundin, J.

Evaluation of Bone Metabolic Markers as Indicators of Osteo- 231 penia in Climacteric Women

Pansini, F.; Bonaccorsi, G.; Calisesi, M.; Farina, A.; Levato, F.; Mazzotta, D.; Bagni, B.;

Mollica, G.

Endogenous Digoxin-Like Immunoreactivity Measured in 236

Seminal Fluid from a Normal Male Population

Vadazs, A.; Jakobi, P.; Stoler, J.; Makler, A.; Krivoy, N.

Case Reports 
Delay in the Diagnosis of Rupture of the Uterus due to Epi- 239 dural Anesthesia in Labor Abraham, R.; Sadovsky, E.

Maternal Hemorrhagic Complications following Prophylactic 241 Low-Dose Aspirin and Dipyridamole Therapy ReubinofT, B.E.; Eldor, A.; Laufer, N.; Sadovsky, E.

Third Trimester Torsion of Persistent Ovarian Cyst following 244

Ovarian Hyperstimulation - An Unusual Cause of Preterm

Labor

Goshen, R.; Lavy, Y.; Hochner-Celnikier, H.; Milwidsky, A.

Independent Origin of Uterine Leiomyomas with Karyotypi- 246 cally Identical Alterations Nilbert, M.; Strömbeck, B.

Author Index 249

Subject Index 251

S. Karger

Medical and Scientific Publishers Basel · München a Paris · London New York · New Delhi ·

Bangkok Singapore $\cdot$ Tokyo $\cdot$ Sydney

Drug Dosage

The authors and the publisher have exerted every effort to ensure that drug selection and dosage set forth in this text are in accord with current recommendations and practice at the time of publication. However, in view of ongoing research, changes in government regulations, and the constant flow of information relating to drug therapy and drug reactions, the reader is urged to check the package insert for each drug for any change in indications and dosage and for added warnings and precautions. This is particularly important when the recommended agent is a new and/or infrequently employed drug.

All rights reserved.

No part of this publication may be translated into other languages, reproduced or utilized in any form or by any means, electronic or mechanical, including photocopying, recording, microcopying, or by any information storage and retrieval system, without permission in writing from the publisher or, in the case of photocopying, direct payment of a specified fee to the Copyright Clearance Center (see 'Information for Readers and Subscribers').

(C) Copyright 1992 by S. Karger AG, P.O. Box, CH-4009 Basel (Switzerland) Printed in Switzerland on acid-free paper by Thür AG Offsetdruck, Pratteln

IV

Contents 